experiment. When the animals developed abdominal lesions on the third day, they were divided into control and experimental groups, and the latter were given daily injections of $50 \mathrm{mgm}$. of brain extract. As early as two days after the injection of the brain extract, definite improvement was noted in the experimental animals, and by the fourteenth day of the experiment or the eleventh day of treatment all animals were completely healed. There was no mortality. The abscesses in the control group, however, continued to progress and resulted in final mortality of 60 per cent and a delay in healing of the remsining 40 per cent of three weeks.

Conclusions. A factor has been extracted from ox brain, spleen, heart and kidney tissue, which in vitro is capable of converting yellow $S$ forms of $S$. aureus to white $R$, the latter having biochemical characteristics quite different from the former. Moreover, this organism retains its altered morphological and biochemical characteristics in vivo and is definitely less virulent than the yellow $S$ form. Prophylactic and therapeutic tests with the brain extract show that it is effective in preventing and treating $S$. aureus infections, the efficacy of the treatment probably resulting from a decrease in virulence of the organism produced as a result of alteration in its morphological and biochemical characteristics.

LEO G. Nutrni.

Eva Maria Lynoh, S.S.J.

Institutum Divi Thomae,

Institute of Scientific Research,

Cincinnati, Ohio.

Nov. 8, 1944. Sperti, Loofbourow and Dwyer, Studies Inst. Divi Thomas, 1, 163
$(1937)$.

Fardon and Sullivan, Studies Inst. Divi Thomae, 2, 39 (1938-39).

- Cook, Kreke, Giersch and Schroeder, Science, \$8, 616 (1941).

- Schroeder and Hollencamp, Studies Inst. Divi Thomae, 3, 193 (1941).

${ }^{5}$ Nutini and Kreke, J. Bact., 44, 661 (1942).

\section{Differentiation between Eosinophils and Pseudo-eosinophils of Rabbits' Blood by means of a Peroxidase Reaction}

THr difficulty of distinguishing between eosinophil and pseudo-eosinophil leucocytes in rabbits' blood stained with the usual blood stains is well known. Ehrlich's triglycerin mixture, in which the eosinophil granules are shown up specifically in yellow, gives irregular results and, in general, nather unsatisfactory smears. Recently, I deseribed a new technique for the peroxidase reaction on leucocytes in human blood films employing 2,6-dichlorphenol-indophenol' ${ }^{1}$ This technique applied to films of rabbits' blood allows the observer easily to single out the eosinophil leucocytes, even under relatively low power (for example, $\times 200)$.

The most suitable procedure is to treat for $5-10$ min, fresh, air-dried, formol-alcohol fixed blood films with a mixture of 0.05 per cent aqueous solution of 2,6-dichlorphenol-indophenol (4 pt.) and 0.5 per cent solution of neutral red ( 1 pt.), to every 5 c.c. of which four drops of hydragen peroxide (4 vol. per cent) had been added prior to use. After a short wash, the film is blotted dry and oil is directly applied. Under these conditions the cytoplasm of the eosinophil leucacytes is densely packed with heavily stained large spherical granules (up to $1.5 \mu$ in diameter); almost every granule shows a dark purplish-black periphery and

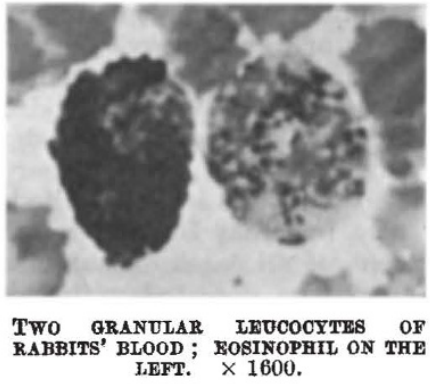

a somewhat lighter interior, the colour of which ranges between mauve and a dirty greyish blue, while the pseudo-eosinophil granular leucocytes show much smaller (about $0.5 \mu$ ) and scattered dark purplish granules, some of which are more ovoid or rod-shaped than spherical; the granules vary in size, and some, if big enough, also appear as dark rings with a tiny light centre. The contrast between the two types of cells is particularly striking after a short reaction time when only a limited number of granules in each pseudo-eosinophil is stained. If the time is prolonged to $20 \mathrm{~min}$. or more, many more granules in each pseudo-eosinophil become positive. This observation is opposed to the view that the enzyme is situated actually on or in the granules.

Measurements of cell diameters made with these preparations show the eosinophils to vary from 10 to $12 \mu$, and the other granular leucocytes from 7 to $10 \cdot 5 \mathrm{l}$. In differential counts the eosinophils are found to represent 1 per cent or less of the white blood corpuscles, which figure agrees well with Klieneberger's data ${ }^{2}$. The relative number of basophils has to be determined by means of one of the usual blood stains.

Department of Physiology,

F. $\mathrm{J}_{\mathrm{ACOBY}}$.
Medical School,
Birmingham, 15. June 19.

1 Jacoby, F., J. Physiol., 108, 25 P (1944).

"Klieneberger, C., "Die Blutmorphologie der Laboratoriumstiere" (Leipzig, 1927).

\section{Cosmic Radiation Observed at the Col du Lautaret, Hautes-Alpes}

Les deux clichés reproduits ici ont été pris dans l'été 1943 au col du Lautaret $(2,060 \mathrm{~m}$.) au cours d'une mission organisée par M. Leprince-Ringuet. La détente de la chambre de Wilson était commandée par trois compteurs dispersés sur une aire d'une dizaine de m.2; deux de ces compteurs étaient couverts de 4 ou de $8 \mathrm{~cm}$. de plomb. Les gerbes des figs. 1 et 2 sont dono secondaires de grandes gerbes d'Auger particulièrement riches en rayonnement pénétrant.

La gerbe de la fig. 1 eat issue de $14 \mathrm{~mm}$. de laiton. Flle est essentiellement constitué de einq paires serrées régulièrement disposées et faisant entre elles un angle d'environ $1 / 10$ de radian. Les premières deux paires sont visibles sur les images latérales, les trois autres malheureusement pas.

La gerbe eomprend une perticule lourde (meson ou proton) arrêtée dans l'écran de $15 \mathrm{~mm}$. de plomb. Les deux trajectoires de la première paire paraissent donner un secondaire : la première traverse ou donne un secondaire peu dévié $\left(5^{\circ}\right)$; la deuxième donne un 